\title{
O RESTRYKCJACH LEKSYKALNYCH W UŻYCIU UDMURCKICH PRZYPADKÓW KOŃCÓWKOWYCH*
}

\author{
ROBERT BIELECKI \\ Uniwersytet im. Adama Mickiewicza w Poznaniu \\ Wydział Neofilologii \\ Instytut Językoznawstwa \\ al. Niepodległości 4, 61-874 Poznań, Polska \\ e-mail: robertbi@amu.edu.pl \\ (nadesłano 28.09.2017; zaakceptowano 8.10.2017)
}

\section{Abstract \\ On lexical restrictions in the use of Udmurt desinential cases}

Case is traditionally viewed as a grammatical category. Grammar is associated with regularity, and in this sense, it is very often opposed to the lexis. Nevertheless, in every language, even the most regular lingual mechanism is subject to some lexical restrictions. In this paper, an attempt is made to describe the principal mechanisms of the functioning of this phenomenon in the Udmurt desinential case system. As it turns out, in spite of the fact that the nominative is the case of such an indispensable syntactic category for a sentence as the subject, its diathetic meaning is at the end of the day determined by the lexical meaning of the verb. The syntagmatic appearance of the accusative, the other so-called grammatical case in the Udmurt language, is also restricted by the same factor. In turn, the signification of the genitive in its strictly adnominal function seems to be determined by the lexis of both components of the adnominal syntagm. In the use of the other Udmurt cases, globally speaking, even greater irregularity can be observed. Their use is determined either by the verbal or by the substantival lexical context. In some cases both factors co-occur.

\footnotetext{
*Dziękuję rodzimym użytkownikom języka udmurckiego, pani doc. dr Oldze Strelkovej, pani Oldze Urasinovej i pani Ladzie Perevoščikovej za konsultacje językowe odnośnie do sformułowanych przeze mnie egzemplifikacji.
} 


\title{
Key words
}

Udmurt, case, grammar, lexis, restrictions.

\begin{abstract}
Abstrakt
Przypadek jest pojmowany zazwyczaj jako kategoria gramatyczna. Gramatyka jest kojarzona z regularnością i w tym sensie jest nader często przeciwstawiana leksyce. Jednak nawet najbardziej regularny mechanizm językowy podlega w każdym języku jakimś restrykcjom o charakterze leksykalnym. Niniejszy artykuł stanowi próbę opisu głównych mechanizmów funkcjonowania tego zjawiska w końcówkowym systemie przypadkowym języka udmurckiego. Jak się okazuje, pomimo iż nominativus jest przypadkiem takiej niezbywalnej dla zdania kategorii syntaktycznej, jaką jest podmiot, to jego znaczenie diatetyczne jest $\mathrm{w}$ ostatecznym rozrachunku determinowane przez znaczenie leksykalne czasownika. Syntagmatyczne manifestowanie się accusativu, kolejnego tzw. przypadka gramatycznego w języku udmurckim, także jest ograniczane przez ten sam czynnik. Sygnifikacja genetivu w jego funkcji stricte adnominalnej wydaje się zdeterminowana $\mathrm{z}$ kolei przez znaczenie leksykalne obu komponentów syntagmy adnominalnej. W użyciu pozostałych przypadków udmurckich można dostrzec globalnie jeszcze mniej regularności. Ich użycie zdeterminowane jest albo przez leksykalny kontekst czasownikowy, albo przez rzeczownikowy. W pewnych okolicznościach współwystępują oba czynniki.
\end{abstract}

\section{Słowa kluczowe}

Udmurcki, przypadek, gramatyka, leksyka, restrykcje.

\section{Uwagi wstępne}

W literaturze przedmiotu przypadek rozumiany jest jako kategoria morfologiczna (morfosyntaktyczna) kodująca relacje między obiektami. Jako że każde zdanie w każdym języku odnosi się do jakichś obiektów i relacji między nimi, przypadek jest kategorią wszechobecną. Sposób kodowania relacji przypadkowych na płaszczyźnie wyrażania jest w zasadzie obojętny. Zawsze jednak jakiś jest i poszczególne przypadki dyskretnie (tj. skokowo) się od siebie pod tym względem różnią. Trudno bowiem wyobrazić sobie jakąś zupełną amorficzność w tak istotnej z punktu widzenia komunikacji językowej sprawie.

Należący do rodziny języków ugrofińskich język udmurcki, używany przez ok. 463 000 ludzi głównie na terytorium Republiki Udmurckiej w Rosji ${ }^{1}$, oparł - jeżeli można tak powiedzieć - sygnifikację znaczeń przypadkowych przede wszystkim na mechanizmie końcówkowym. W porównaniu z mechanizmami alternatywnymi szczególność mechanizmu końcówkowego polega jedynie na tym, że ułatwia on znacząco iden-

1 В.Е. Владыкин, Л.С. Христолюбова. Удмуртъёс. Ижевск: Удмуртия, 2008, s. 24. 
tyfikację form przypadkowych jako segmentalnie kontynualnych. Końcówkowości jednak nie można w żadnym wypadku uznawać jako warunek sine qua non deskryptywnej relewantności przypadka jako takiego.

Przypadek jest kojarzony z kategorią gramatyczną, tj. zbiorem wyrazów, które się charakteryzują jakimiś powtarzalnymi, regularnymi eksponentami odpowiednich znaczeń i funkcji składniowych. W miejscu tym nieustannie narzuca się pytanie o, nieco kolokwialnie wręcz pobrzmiewającą, liczbę przypadków w danym języku. Odróżnienie tzw. podejścia onomazjologicznego, tj. „od formy do znaczenia” - punkt widzenia odbiorcy komunikatu, od semazjologicznego, tj. „od znaczenia do formy” - punkt widzenia nadawcy komunikatu ${ }^{2}$, stanowi jedynie pozorny trop prowadzący do rozwikłania tej aporii metodologicznej. Oba podejścia są bowiem komplementarne, tj. dopełniają się nawzajem. Nie sposób wyróżnić jakichkolwiek form językowych nie znając przypisanych do nich znaczeń, tak samo jako nie sposób uzmysłowić sobie jakichkolwiek znaczeń, by dopiero potem poszukiwać dla nich ewentualnych formalnych realizacji. Nasz intelekt pozwala nam oczywiście na traktowanie aspektu formalnego i semantycznego zjawisk językowych w odosobnieniu, o czym świadczą nieprzebrane opracowania, które to centralne rozróżnienie honorują. Nie oznacza to jednak, byśmy byli w stanie wskazać epistemiczną pierwotność któregokolwiek z nich. Wobec powyższego panujący w tej kwestii uzus metodologiczny jest taki: badacz w mniej lub bardziej zawoalowany sposób oświadcza, iż z jego punktu widzenia - za który ponosi odpowiedzialność - relewantne dla przypadka formalno-semantyczne regularności języka można w najbardziej adekwatny sposób uchwycić za pomocą takiej a takiej ilości odpowiednich klas wyrazowych zwanych przypadkami.

We współczesnym literackim języku udmurckim wyróżnia się piętnaście ${ }^{3}$ przypadków końcówkowych":

2 Por. O. Jespersen. The Philosophy of Grammar. New York: The Norton Library, 1965, s. 17; A. Bogusławski, E. Drzazgowska. Język w refleksji teoretycznej. Przekroje historyczne. Warszawa: Katedra Lingwistyki Formalnej Uniwersytetu Warszawskiego, 2016, s. 246-247.

3 F. Wiedemann. Grammatik der wotjakischen Sprache nebst einem kleinen wotjakisch-deutschen und deutsch-wotjakischen Wörterbuche. Tallin: Kluge \& Ströhm, 1851, s. 17-44; R. Bartens. Permiläisten kielten rakenne ja kehitys. Helsinki: Suomalais-Ugrilainen Seura, 2000, s. 77-79; Л. Карпова. Особенности функиионирования падежей в северных диалектах удмуртского языка. „Вестник Красноярского государственного педагогического университета им. В.П. Астафьева” 2011, nr 3, s. 231-233; Н. Кондратьева. Категория падежа имени существительного в удмуртском языке. Ижевск: Удмуртский университет, 2011, s. 16-23.

4 Podobną funkcję spełniają w języku udmurckim bardzo licznie występujące apozycje, a dokładniej postpozycje, które wykazują różny stopień integralności z rdzeniem leksykalnym, do którego się odnoszą. Począwszy od:

(i) całkowitej linearnej rozdzielalności wzmacnianej dodatkowo faktem występowania w leksykonie języka udmurckiego ich pełnoleksykalnych ekwiwalentów, np. Книга ӭсок вылын 'Książka jest na stole' (por. выл 'powierzchnia'), poprzez:

(ii) apozycje nieposiadające takich leksykalnych ekwiwalentów, np. Москваысь Ижкаре поездэн одӥг нунал ӥоже вуыны луэ 'Z Moskwy do Iżewska można dojechać pociągiem w jeden dzień', których formy nie mogą występować bez rzeczownika, do którego się odnoszą (por. zdanie z bblлың z poprzedniego punktu z: Кыллюкам ӝсок улын, нош книга вылын 'Słownik jest pod stołem, a książka na wierzchu'), aż po: 
(i) nominativus

(ii) genetivus

(iii) dativus

(iv) accusativus

(v) ablativus

(vi) instrumentalis

(vii) illativus

(viii) inessivus

(ix) elativus

(x) approximativus

(xi) terminativus

(xii) prolativus

(xiii) egressivus

(xiv) abessivus

(xv) adverbialis

\section{termin udmurcki}

ниман вошбет

возьматон вошбет

сётон вошбет

адӟон вошбет

люкон вошбет

тэсьтон вошбет

пырон вошбет

интьян вошбет

потон вошбет

лькктон вошбет

вуон вошбет

ортчон вошбет

кошкон вошьет

кельтон вошбет

тупан вошбет

\section{końcówki ${ }^{5}$}

$-\varnothing$

$-\pi э н$

$-\pi b l$

$-\varnothing,-э 3,-e 3,-\ni,-e,-b l 3,-m b l^{6}$

$-\pi \ni c b$

$-\ni \mathcal{H},-e \mathcal{H},-\boldsymbol{b l H}$

$-\ni,-e,-b l,-\pi a,-\varnothing$

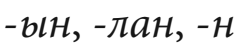

$-b l c b,-\pi a c b,-c b$

$-\pi a{ }^{2}$

$-03 b$

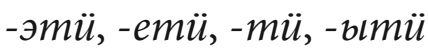

-ысен, -ласен, -сен

$-m \ni \kappa$

$-Я$

Prezentacja inwentarza przypadków wraz z przysługującymi im sygnifikatorami (morfologicznymi wykładnikami) to zaledwie jeden z pierwszych kroków prowadzących do skonstruowania gramatyki przypadka badanego języka. Gramatyka to zazwyczaj dziedzina językoznawstwa zajmująca się zjawiskami językowymi cechującymi się stosunkowo wysoką regularnością. W tym sensie gramatyka przeciwstawiana jest leksyce zajmującej się zjawiskami odosobnionymi, idiosynkratycznymi. Badania empiryczne poszczególnych języków naturalnych wydają się jednak niezmiernie potwierdzać fakt, iż nawet najbardziej regularny mechanizm języka nigdy nie jest zregulary-

(iii) apozycje zatracające $\mathrm{w}$ pewnych rejestrach języka taką oddzielalność, wykazujące pewien stopień erozji fonetycznej, np. dialektalne, północnoudmurckie мон дӥням > монням 'u mnie', por. Әüнь 'rdzeń, pień; podstawa; dom' (por. K. Rédei. Die Postpositionen im Syrjänischen unter Berücksichtigung des Wotjakischen. Budapeszt: Akadémiai Kiadó, 1962.).

5 Jak przystało na język aglutynacyjny, końcówki udmurckich przypadków wykazują zarówno stosunkowo niski stopień kumulacji różnych funkcji gramatycznych, jak i stosunkowo niski stopień allomorfizmu. Zjawiska te są szczególnie jaskrawe w przypadku tzw. deklinacji absolutnej (огшоры вошъян) prezentowanej w tabeli, w ramach której formy imienne nie przyjmują sufiksalnych wykładników osoby.

${ }^{6}$ W niniejszym artykule wszystkie wymienione końcówki traktowane są jako końcowki accusativu pomimo następujących przypadków homonimii: (i) nu/Ø - zarówno nominativus nieokreślony ('jakiś chłopiec'), jak i accusativus nieokreślony ('jakiegoś chłopca'), (ii) nu/e3 - zarówno nominativus określony ('ten chłopiec'), jak i accusativus określony ('tego chłopca'), (iii) nu/ez - zarówno określony nominativus nieokreślony pod względem osoby ('ten chłopiec'), jak i określony nominativus określony pod względem osoby ('(ten) jego chłopiec'), (iv) мypm/ə - zarówno illativus nieokreślony ('w człowieka'), jak i accusativus określony ('tego człowieka') (por. M.A. Castrén. Elementa Grammatices Syrjaenae. Helsinki: Officina typographica heredum Simelii, 1844, s. 18; Б. Серебренников. Историческая морфология пермских языков. Москва: Издательство Академии Наук СССР, 1964, s. 11-12; S. Csúcs. A votják tárgyról. „Nyelvtudományi Közlemények” 2003, nr 100, s. 126-136.). 
zowany całkowicie. Na każdy mechanizm gramatyczny nakładane są jakieś restrykcje leksykalne.

Celem niniejszego artykułu jest naświetlenie głównych mechanizmów funkcjonowania tego zjawiska $\mathrm{w}$ ramach końcówkowego systemu przypadkowego języka udmurckiego.

\section{Nominativus}

Już w starożytnej Grecji, a więc w kolebce językoznawstwa okcydentalnego, zdawano sobie sprawę z wyjątkowości składniowego charakteru nominativu. Wyrazem tego przekonania jest klasyczny podział przypadków na:

(i) $\pi \tau \tilde{\omega} \sigma \iota \varsigma \dot{o} \rho 9 \dot{\eta} \quad$ 'przypadek prosty/ niezależny' oraz

(ii) $\pi \tau \tilde{\omega} \sigma \varepsilon \iota \varsigma \pi \lambda \dot{\alpha} \gamma \iota \alpha \iota \quad$ 'przypadki pochyłe / zależne'.

Miano przypadka niezależnego przypisano nominativowi jako przypadkowi podmiotu (determinatum absolutum wysaturowanego logu determinacyjnego ${ }^{7}$ ). Przypadki zależne to pozostałe przypadki oprócz vocativu, który nie wstępuje w związki składniowe z żadnym wyrazem w zdaniu.

Najpełniejszym przejawem komunikatu językowego jest zdanie. Jeżeli zdanie nie przyjmuje formy defektywnej ze względu na przeładowanie redundancyjne, to składa się ono w swej fundamentalnej postaci z dwóch członów:

(i) podmiotu $\mathrm{w}$ formie rzeczownika oraz

(ii) orzeczenia $\mathrm{w}$ formie czasownika determinującego podmiot.

Podmiot i orzeczenie to zatem dwie niezbywalne części zdania. Inaczej zdania po prostu niepodobna sobie wyobrazić. Zdanie orzeka bowiem coś o czymś. Zdania języka polskiego typu Pada są bezpodmiotowe tylko z pozoru. Są one bowiem defektywnymi manifestacjami zdań pełnych typu Deszcz pada .

Przypadek określany terminem ниман вошъет 'nominativus', jest przypadkiem podmiotu w języku udmurckim, np.:

(1) Студент/Ø пук/е.

student-NOM siedzieć-PRAES III SG

[STATIVUs]

'Student siedzi'.

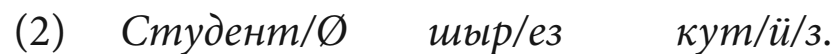

student-NOM mysz-ACC złapać-I PRAET-III SG

[AGENS] [PATIENS]

'Student złapał mysz.'

\footnotetext{
${ }^{7}$ J. Bańczerowski. Systems of Semantics and Syntax. A Determinational Theory of Language. Warszawa-Poznań: Państwowe Wydawnictwo Naukowe, 1980, s. 65-85.

${ }^{8}$ L. Zabrocki. U podstaw struktury i rozwoju języka. Warszawa-Poznań: Państwowe Wydawnictwo Naukowe, 1980, s. 136.
} 
(3)

$\begin{array}{ll}\text { Cтудент/Ø } & \text { нюлэс/тӥ } \\ \text { student-NOM } & \text { las-PROLAT } \\ \text { [LOCATOR] } & \text { [LOCUs] } \\ \text { 'Student chodzi po lesie.' }\end{array}$

(4)

$\begin{array}{ll}\text { Cmудент/Ø } & \text { nрофессор/льl } \\ \text { student-NOM } & \text { profesor-DAT } \\ \text { [BENEFACTOR] } & \text { [BENEFICIENT] } \\ \text { 'Student pomaga profesorowi.' }\end{array}$

ветл/э.

chodzić-PRAES III SG

W świetle tego, co powiedziano do tej pory, na pierwszy rzut oka wydawać by się mogło, że nie ma nic bardziej regularnego (gramatycznego) w języku udmurckim od występowania nominativu jako przypadka podmiotu, tj. kategorii syntaktycznej obecnej w każdej niedefektywnej manifestacji zdania. Okazuje się jednak, że z semantycznego punktu widzenia mamy do czynienia $\mathrm{z}$ wieloma odmiankami tego samego przypadka. Jak wskazują na to już glosy, nominativus w zdaniu (1) koduje stativus, czyli aktanta czasownika nieprzechodniego, byt odnoszący się do pewnego stanu. W zdaniu (2) nominativus koduje agensa, czyli aktywnego uczestnika zdarzenia. W zdaniu (3) - locatora, czyli byt gdzieś się znajdujący, a w zdaniu (4) - benefactora, czyli kogoś w rodzaju dobroczyńcy, dawcy. O tym, które znaczenie relewantne dla kategorii diatezy - stativu, agensa, locatora, benefactora itd. - przenosi nominativus, dowiadujemy się dopiero, gdy ujawniony zostanie czasownik (tj. najczęściej dokładnie jego rdzeń leksykalny). W tym świetle nominativus w języku udmurckim jawi się jedynie jako leksykalne uzupełnienie członu podrzędnego, czyli czasownika, determinującego znaczenie diatetyczne przypadka. Innymi słowy, jeżeli ktoś mówi пуке 'siedzi', to implikuje stativus, kogoś lub coś, co siedzi (np. студент 'student', пуны 'pies', курег 'kura' itd.). Wyraz студент w zdaniu (1) Студент пуке nie wnosi nic ponad to, że siedzi student, a nie pies czy kura.

Jak widać, nominativus w języku udmurckim jako przypadek determinatum absolutum wiedzie $\mathrm{w}$ porównaniu $\mathrm{z}$ pozostałymi przypadkami prym $\mathrm{w}$ nieokreśloności swego statusu diatetycznego. Przy przechodzeniu do następnych przypadków nieokreśloność ta dyskretnie spada. Wobec tego siłą rzeczy analogicznie jest z rozmiarem sygnifikatora odpowiednich znaczeń przypadkowych. Przy przechodzeniu od nominativu do następnych przypadków rozmiar sygnifikatora także dyskretnie zmniejsza się dochodząc do takich rozmiarów, aż pokrywa się on właściwie z formą przypadkową rzeczownika. Wypowiadając słowo нюлэстӥ 'po lesie' należące do prolativu nie potrzebujemy żadnego kontekstualnego wsparcia, by jednoznacznie zidentyfikować przenoszone przezeń diatetyczne znaczenie loci 'miejsca'. Wyraz студент 'student' nabiera znaczenia locatora idącego $\mathrm{w}$ parze $\mathrm{z}$ locō dopiero $\mathrm{w}$ połączeniu $\mathrm{z}$ takim czasownikiem jak na przykład ветлэ 'chodzi'.

Mamy tutaj do czynienia najwyraźniej z pewnym głębszym mechanizmem ekonomizacji środków wyrazu. Język przejawia się w zdaniach. Nawet jeżeli wymawiamy tylko jedno słowo, np. kałuża, to słowo to domyślnie wbudowane jest w całe zdanie, np. Uważaj, tuż przed toba jest kałuża. Dlatego nie ma potrzeby sygnalizowania znaczeń przy każdym odnośnym wyrazie, który jest nieco paradoksalnie bardziej abstrak- 
cyjny od zdania' . Obok takich wieloznacznych diatetycznie kategorii przypadkowych jak nominativus mamy w języku udmurckim kategorie przypadkowe diatetycznie mniej wieloznaczne (a właściwie wręcz jednoznaczne), na przykład accusativus (por. zdanie (2)). Jest to mechanizm blokujący wieloznaczność na planie syntagmatycznym. Ze zdania typu:

$\begin{array}{lll}\text { Cmудент/Ø } & \text { nрофессор/ез } & \text { aд̈̈/e. } \\ \text { student-NOM } & \text { profesor-ACC } & \text { widzieć-PRAES III SG } \\ \text { [AGENs] } & \text { [PATIENS] } & \\ \text { 'Student widzi profesora. } & \end{array}$

wynika, że to profesor jest widziany przez studenta, a nie na odwrót. Leksyka jest wprzężona jedynie w ujednoznacznianie roli semantycznej nominativu. Przeciwstawienie syntagmatyczne nominativu (agensa) accusativowi (patiensowi) i jednoczesne sygnifikowanie tego ostatniego jest osiągane za pomocą środków gramatycznych (por. końcówkę accusativu -e3 vs. końcówkę nominativu -Ø).

\section{Accusativus}

Zawrotną karierę w językoznawstwie zrobiła także klasyfikacja przypadków na:

(i) przypadki gramatyczne / logiczne i

(ii) przypadki konkretne / semantyczne.

Spośród przypadków znanych w językach indoeuropejskich, miano przypadka gramatycznego przypisywano zazwyczaj nominativowi, genetivowi i accusativowi. Z kolei jako przypadki semantyczne określano takie przypadki jak dativus, locativus, ablativus i instrumentalis.

Hjelmslev i Jakobson rozpatrując przypadki jedynie z semantycznego punktu widzenia stoją na stanowisku, iż podział przypadków na gramatyczne i konkretne jest bezprzedmiotowy, ponieważ przypadki uznawane tradycyjnie za gramatyczne mogą występować w funkcji przypisywanej przypadkom konkretnym (tj. jako niezwiązane dopełnienia czasownika), jak i na odwrót; przypadki uznawane tradycyjnie za konkretne mogą występować w funkcji przypisywanej przypadkom gramatycznym (tj. jako związane dopełnienia czasownika ${ }^{10}$. Koryfeusz polskiej myśli lingwistycznej Jerzy Kuryłowicz w artykule Zagadnienie klasyfikacji przypadków twierdzi, iż klasyfikacja taka jednak ma rację bytu przy założeniu, że da się rozróżnić w odniesieniu do każdej formy przypadkowej jej funkcję prymarną i sekundarną ${ }^{11}$.

Końcówka łacińskiego accusativu -em w hostem occidere 'zabić wroga' funkcjonuje według Kuryłowicza jedynie w charakterze syntaktycznego subordynatora rzeczow-

9 Por. G. Frege. Pisma semantyczne. Warszawa: Państwowe Wydawnictwo Naukowe, 1977, s. 72-73.

10 L. Hjelmslev. La catégorie des cas. „Acta Jutlandica” 1937, nr IX 2, s. 1-184; R. Jakobson. Selected Writings II. World and Language. The Hague-Paris: Mouton, 1971, s. 23-71.

11 J. Kuryłowicz. Studia językoznawcze. Wybór prac opublikowanych w języku polskim. Warszawa: Państwowe Wydawnictwo Naukowe, 1987, s. 181-184. 
nika w stosunku do czasownika tranzytywnego, nie wnosząc do zwrotu żadnego własnego wkładu semantycznego. Natomiast końcówka łacińskiego ablativu -o w gladio hostem occidere 'zabić wroga mieczem', niebędącego rządzonym przez czasownik occidere 'zabić, poza oczywistym sygnalizowaniem syntaktycznej subordynacji rzeczownika w stosunku do czasownika, ze względu na swój charakter adwerbialny ma swoją własną zawartość semantyczną (sygnifikuje instrument). W polskim zwrocie Chorował dwa tygodnie czy łacińskim civitate potiri 'rządzić państwem' mamy do czynienia z sytuacją odwrotną: accusativus $d w a$ tygodnie użyty został konkretnie (okolicznik czasu), natomiast ablativus civitate - gramatycznie jako przypadek rządzony przez czasownik potiri ${ }^{12}$.

Przypadki gramatyczne (np. indoeuropejski accusativus) mają swoją funkcję czysto syntaktyczną w sensie kuryłowiczowskim jako prymarną, natomiast funkcję semantyczną (czy też syntaktyczno-semantyczną) jako sekundarną. Z kolei przypadki konkretne (np. ablativus) mają swoją funkcję semantyczną jako prymarną, natomiast funkcję czysto syntaktyczną jako sekundarną. Użycia sekundarne mają to do siebie, że podlegają (o wiele ściślejszym) kontekstualnym restrykcjom syntaktyczno-semantycznym. Na przykład semantyczna funkcja polskiego accusativu dwa tygodnie w Chorował dwa tygodnie jest rezultatem współdziałania następujących czynników: 1) aspektu niedokonanego czasownika, 2) nieprzechodniości czasownika i 3) oznaczania przez rzeczownik okresu czasu (tydzień).

Udmurcki accusativus, jak przystało na przypadek w sensie kuryłowiczowskim wybitnie gramatyczny, w swej funkcji prymarnej stanowi dopełnienie bliższe czasowników przechodnich, np.:

(6) $\mathrm{Мон/ \varnothing} \mathrm{тон/э} \mathrm{яратӥ/сько/Ø.}$

ja-NOM ty-ACC kochać-PRAES-I SG

'Ja kocham cię.'

(7) Мон/Ø та адями/ез кемалась тодӥ/сько/Ø.

ja-NOM ten człowiek-ACC oddawna znać-PRAES-I SG

'Ja znam tego człowieka od dawna.'

(8) Валь/ёс/Ø та турьин/эз мыло-кьцо си/ё.

koń-PL-NOM to siano-ACC chętnie jeść-PRAES III PL

'Konie chętnie jedzą to siano'.

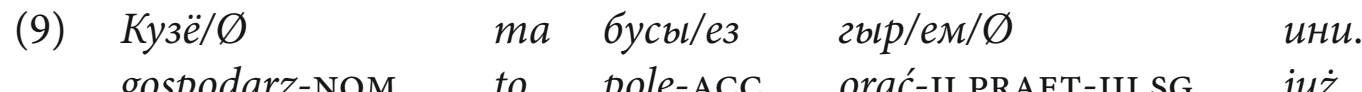

gospodarz-NOM to pole-ACC orać-II PRAET-III SG już

'Gospodarz to pole już (ponoć) zaorał'.

12 Por. udmurckie pojęcia: кужмо кивалтон 'rząd mocny' vs. ляб кивалтон 'rząd słaby' (Д. Ефремов. Удмурт кылысь каронкыллэн управлениез сярысь. „Вестник Удмуртского университета. История и филология" 2009, nr 1, s. 43-54.). 
Кулак/Ø вал/эз лумбыт $у ж а / m / э$. kułak-NOM koń-ACC calydzień pracować-CAUs-PRAES III SG 'Kułak każe pracować koniowi cały dzień.'

Omawiane użycie accusativu w języku udmurckim charakteryzuje się wysokim stopniem regularności. We wszystkich imiennych kategoriach homoleksji tego języka, inaczej paradygmatach deklinacyjnych, odnajdujemy bowiem słowoformy określane mianem accusativu: тон/э 'cię,', адями/ез 'człowieka', турын/эз 'trawę, siano', бусы/ез 'pole', вал/эз 'konia' itd., które niezależnie od swojego znaczenia leksykalnego mogą potencjalnie spełniać tę samą funkcję. Z czasownikowego punktu widzenia jednak manifestowanie się udmurckiego accusativu jest dalekie od tak wysokiego stopnia regularności. Czasowniki przechodnie - oprócz nielicznych wyjątków (por. kauzatyfikator - $m(b l)-\mathrm{w} y ж a / m b l / H b l$ 'kazać pracować, zmuszać do pracy' vs. yжa/Hbl 'pracować) - nie charakteryzują się w języku udmurckim żadnym specyficznym afiksem tranzytyfikującym. By odzwierciedlić rzeczone syntagmatyczne funkcjonowanie udmurckiego accusativu $\mathrm{w}$ połączeniu $\mathrm{z}$ czasownikiem rządzącym, $\mathrm{w}$ ostatecznym rozrachunku nie pozostaje właściwie nic innego jak enumeracja czasowników łączących się z tym przypadkiem, np. яратыны 'kochać, mодыны 'wiedzieć, znać, сиьıны 'jeść, гырыны 'orać' itd.

\section{Genetivus}

W omawianym ujęciu Kuryłowicza indoeuropejski genetivus traktowany jest jako przypadek gramatyczny w funkcji genetivu subiectivu i genetivu obiectivu. Pozostałe użycia genetivu Kuryłowicz określa jako sekundarne.

Charakterystyczną cechą języka udmurckiego (lub szerzej - języków permskich ${ }^{13}$ ) jest brak genetywizacji dopełnienia bliższego w procesie substantywizacji czasownika. Wyraz sygnifikujący patiensa w tego typu frazach zachowuje, jeżeli można tak ująć, końcówkę accusativu. Język udmurcki zatem dysponuje jedynie genetivem subiectivem. Porównajmy:

$\begin{array}{lll}\text { Co/Ø } & \text { cmyденть/ëc/mbl } & \text { дышет/э. } \\ \text { on-NOM } & \text { student-PL-ACC } & \text { nauczać-PRAES III SG }\end{array}$

'On naucza studentów.'

(12)

on-GEN nauczać-SUBST-III SG-NOM

'jego nauczanie'

$\begin{array}{ll}\text { cmyденmъ/ëc/mbı } & \text { дыıет/он/Ø } \\ \text { student-PL-ACC } & \text { nauczać-SUBST-NOM } \\ \text { 'nauczanie studentów' } & \end{array}$

13 G. Stipa. Funktionen der Nominalformen des Verbs in den permischen Sprachen. Helsinki: Suomalais-Ugrilainen Seura, 1960, s. 70-71. 
Sygnifikacji diatetycznej udmurckiego genetivu subiectivu dotyczyłyby naturalnie te same ograniczenia leksykalne jak w przypadku nominativu (por. rozdział 2).

Jeżeli chodzi o użycia stricte adnominalne, to udmurcki genetivus charakteryzuje się zachowaniami podobnymi do genetivu indoeuropejskiego, tj. szczególną w porównaniu z pozostałymi przypadkami polisemią. W gramatyce współczesnego języka udmurckiego pod redakcją Perevoščikova wyróżniono szereg znaczeń genetivu adnominalnego, które można by pogrupować w następujący sposób ${ }^{14}$ :

(i) possessor, np.

(ii) część, np.

(iii) pochodzenie, np.

(iv) nosiciel cechy, np. дыıшетӥсь/лэн книгаосыз 'książki nauczyciela', Игнат/лэн пельпумъёсыз 'plecy Ignacego',

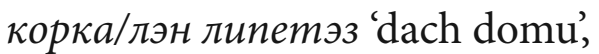

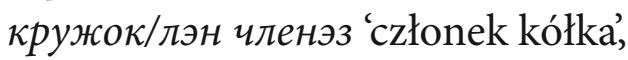
Катя/лэн ньлььз/лэн нылььз 'córka córki Katii', льммыл/лэн тӧдьыез 'biel śniegu'.

Rozmytość sygnifikacji genetivu adnominalnego w języku udmurckim wydaje się wynikać z braku odpowiednich minimalnych syntagm genetywnych i minimalnych syntagm o innym przypadku, w ramach których genetivus kontrastowałby $\mathrm{z}$ tymi przypadkami niejako soczewkując na swojej formie funkcję przenoszenia odpowiedniego znaczenia. W związku z tym sygnifikator docelowych znaczeń genetivu w funkcji stricte adnominalnej rozciąga się praktycznie na całą syntagmę nominalną, włączając w to rdzenie leksykalne stanowiące jej część. Znaczenie tego typu genetivu jest zatem w ostatecznym rozrachunku uzależnione od leksyki łączonych członów nominalnych.

Warto w miejscu tym zwrócić uwagę na charakterystyczną dla języków permskich, pod względem historycznym - jak się wydaje - niewyjaśnioną zadowalająco, alternację genetivu i ablativu w funkcji adnominalnej:

Студент/лэн доре уж/ез/Ø student-GEN pracadomowa-III SG-NOM 'Praca domowa studenta jest na stole.' ґ̈ок выл/ъьн.

stót-na-INESS
Профессор/Ø
студент/лэсь доре уж/з/э
$\pi b \iota \partial \ddot{3} / e$.
profesor-NOM student-ABL
praca domowa-III SG-ACC
czytać-PRAES III SG
'Profesor czyta pracę domową studenta.'

Alternacja ta jednak jest asemantyczna. Ablativus stanowi wariant kombinatoryczny sui generis genetivu, gdy wyraz nadrzędny należy do accusativu (por. (15) cmyдeнm/ лэсь доре уж/3/э 'pracę domową studenta'). W pozostałych przypadkach w tego typu frazach występuje genetivus (por. (14) студент/лэн доре уж/ез (nominativus) 'praca domowa studenta', студент/лэн доре уж/a/з (inessivus) 'w pracy domowej studenta', студент/лэн доре уж/ез сярысь (konstrukcja poimkowa) 'o pracy domowej studenta' itd.). Frazy tego typu nie stanowią zatem minimalnych syntagm przypadkowych.

\footnotetext{
14 Грамматика современного удмуртского языка. Фонетика и морфология. Ред. П.Н. Перевощиков. Ижевск: Удмуртское Книжное Издательство, 1962, s. 79-81.
} 


\section{Pozostałe przypadki}

Kwestię restrykcji leksykalnych, którym podlega użycie pozostałych przypadków końcówkowych w języku udmurckim, należy rozpatrywać w trojaki sposób.

Użycie dativu, ablativu, instrumentalu, illativu, inessivu i elativu jako kuryłowiczowskich przypadków konkretnych w ich funkcji sekundarnej ograniczane jest przez kontekst czasownikowy. Porównajmy dwa następujące zdania:

$\begin{array}{lll}\text { Вын/ы/ } & \text { инженер/ьıн } & y ж a / 3 . \\ \text { brat-I SG-NOM } & \text { inżynier-INESS } & \text { pracować-III SG } \\ \text { 'Mój brat pracował jako nauczyciel. } & \end{array}$
$B b \iota / / b l / \varnothing$
инженер/ьсь
$\kappa о u \kappa / u / 3$.
brat-I SG-NOM
inżynier-ELAT
odejść-I PRAET-III SG
'Mój brat przestał pracować jako nauczyciel.'

Użycie odpowiedniego przypadka związanego dopełnienia czasownika (tutaj inessivu i elativu) związane jest $\mathrm{z}$ wystąpieniem odpowiedniego czasownika. Czasownik ужаны 'pracować' łączy się z okolicznikiem stanu kodowanym za pomocą inessivu, natomiast czasownik кошкыны 'odejść' łączy się z okolicznikiem stanu kodowanym za pomocą elativu.

Użycie dativu, ablativu, instrumentalu, illativu, inessivu, elativu, approximativu, terminativu, prolativu, egressivu, abessivu i adverbialu w ich funkcji prymarnej ograniczane jest przede wszystkim przez kontekst rzeczownikowy. Na przykład w przypadku instrumentalu dopiero znaczenie leksykalne rdzenia rzeczownikowego, do którego została dołączona jego końcówka, determinuje odpowiednie docelowe znaczenie przypadka. W zdaniu (18) instrumentalis przenosi znaczenie instrumentalne, natomiast w zdaniu (19) znaczenie komitatywne:

$\begin{array}{lll}\text { Co/Ø } & \text { поезд/эH } & \text { вy/u/3. } \\ \text { on-NOM } & \text { pociag-INSTR } & \text { przyjechać-I PRAET-III SG } \\ \text { 'On przyjechał pociągiem.' } & \end{array}$

$\begin{array}{lll}\text { Co/Ø } & \text { кHuza/eH } & \text { вy/u/3. } \\ \text { on-NOM } & k s i a \dot{z} k a \text {-INSTR } & \text { przyjechać-I PRAET-III SG } \\ \text { 'On przyjechał z książką.' } & \end{array}$

Determinowanie znaczenia przypadka zarówno przez rzeczownikowy kontekst leksykalny, jak i czasownikowy jest zjawiskiem niewspółmiernie rzadszym. Porównajmy następujące trzy zdania:

\begin{tabular}{|c|c|c|c|c|}
\hline $\begin{array}{l}M u / \varnothing \\
m y \text {-NOM }\end{array}$ & $\begin{array}{l}\text { кылем } \\
\text { zeszły }\end{array}$ & $\begin{array}{l}\text { ap/blceH } \\
\text { rok-EGRESS }\end{array}$ & $\begin{array}{l}\text { татын } \\
\text { tu }\end{array}$ & $\begin{array}{l}\text { ужа/сько/Mbl } \\
\text { pracować-PRAES-I PL }\end{array}$ \\
\hline
\end{tabular}


(21)

Ми/Ø Ижкар/ьсен

my-NOM Iżewsk-EGRESS

'My wyjechaliśmy z Iżewska.' nom/ $\ddot{u} / \mathcal{M b l}$.

wyjechać-I PRAET-I PL

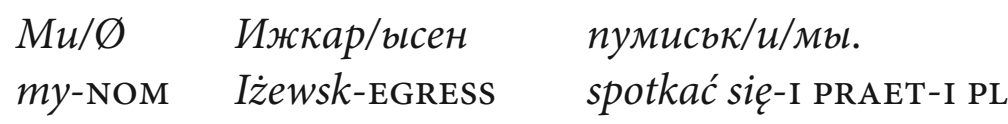

'My spotkaliśmy się w drodze do Iżewska.'

Znaczenie temporalne formy арысен determinowane jest przez rdzeń rzeczownikowy (ap 'rok'). Znaczenie spacjalne formy Ижкарысен - podobnie (Ижкар 'Iżewsk'). Jednakże w zdaniu (21) Ми Ижкарысен потӥмы egressivus przenosi znaczenie źródła czynności, natomiast w zdaniu (22) Ми Ижкарысен пумиськимы komunikuje miejsce, w którym wykonywana czynność jest w swojej fazie środkowej (oddano to za pomocą polskiego wyrażenia $w$ drodze $)^{15}$. Dalsze ujednoznacznienie spacjalnego znaczenia egressivu staje się możliwe zatem dopiero, gdy ujawniony zostanie rdzeń leksykalny czasownika. Jak widać, z czasownikami dynamicznymi (np. nomııны 'wyjechać) nabiera on nieco innego znaczenia niż z czasownikami statycznymi (np. nyмиськьıны 'spotykać się').

\section{Podsumowanie i wnioski}

W literaturze przedmiotu przypadek prezentowany jest nader często jako kategoria gramatyczna. Nie oznacza to jednak, by leksyka - traktowana w pewnych swych aspektach jako przeciwieństwo gramatyki - nie interweniowała w jego użycie. Na każdy, nawet najbardziej zregularyzowany mechanizm gramatyczny bowiem są koniec końców nałożone jakieś restrykcje o charakterze leksykalnym. Celem niniejszego krótkiego artykułu było naświetlenie funkcjonowania tego zjawiska w końcówkowym systemie przypadkowym języka udmurckiego.

$\mathrm{Z}$ pozoru wydawać by się mogło, że nie ma nic bardziej regularnego od użycia udmurckiego nominativu jako przypadka podmiotu, czyli kategorii syntaktycznej obligatoryjnej dla każdej niedefektywnej manifestacji zdania. Z semantycznego punktu widzenia okazuje się jednak, że sygnifikacja diatetyczna nominativu determinowana jest w języku udmurckim w przytłaczającej większości przypadków przez podporządkowany mu czasownik, a dokładniej jego rdzeń leksykalny. W takich okolicznościach nominativus jawi się ni mniej ni więcej jako leksykalne uzupełnienie czasownika.

O ile odnośnie do udmurckiego accusativu, będącego przypadkiem wybitnie gramatycznym, w porównaniu $\mathrm{z}$ nominativem $\mathrm{z}$ diatetycznego punktu widzenia nie można mówić o takiej wielości jego znaczeniowych odmianek, to syntagmatyczne funkcjonowanie accusativu już tak klarowne nie jest. Jego użycie ograniczane jest bowiem przez kontekst czasownikowy. By je odzwierciedlić adekwatnie, w języku udmurckim

15 Рог. Н. Кондратьева. Категория падежа имени существительного в удмуртском языке. Ижевск: Удмуртский университет, 2011, s. 190-191. 
gramatykowi przypadka w ostatecznym rozrachunku nie pozostaje nic innego jak wyliczenie poszczególnych czasowników rządzących accusativem.

Charakterystyczną cechą języka udmurckiego jest brak genetivu obiectivu. Jeżeli chodzi o genetivus subiectivus, to użycie jego odpowiednich semantycznych odmianek podlega takim samym restrykcjom leksykalnym jak w przypadku nominativu. Ze względu na brak minimalnych syntagm przypadkowych, w których genetivus stricte adnominalny kontrastowałby na planie paradygmatycznym $\mathrm{z}$ innymi przypadkami soczewkując na sobie funkcję przenoszenia odpowiedniego znaczenia, znaczenie tego typu genetivu jawi się jako wybitnie rozmyte. Ten stan rzeczy wynika $\mathrm{z}$ faktycznej absorpcji przez sygnifikator przypadka rdzeni leksykalnych stanowiących całą syntagmę przypadkową.

W użyciu pozostałych udmurckich przypadków stwierdza się jeszcze mniej regularności. Ich użycie w funkcji sekundarnej ograniczane jest przez kontekst czasownikowy. Natomiast ich użycie $w$ funkcji prymarnej ograniczane jest przede wszystkim przez kontekst rzeczownikowy. W specyficznych warunkach możliwe jest wystąpienie ograniczeń obu typów jednocześnie.

W świetle przedstawionych faktów należy postawić postulat hierarchicznego formułowania gramatyk języków etnicznych, tzn. zadaniem gramatyk tych byłoby w pierwszym rzędzie prezentowanie faktów najbardziej regularnych. Przejście do faktów mniej regularnych następowałoby w drugiej kolejności. Opisy winny uwzględniać jednak oba aspekty funkcjonowania tzw. kategorii gramatycznych. Dalsze badania nad omawianym zagadnieniem przyczyniłyby się niewątpliwie do pogłębienia naszej wiedzy na temat gramatykalizacji. Sam fakt posiadania afiksów jako nośników odpowiedniej funkcji nie przesądza bowiem o równym nasileniu tego zjawiska w przypadku każdego z nich.

\section{Stosowane oznaczenia i skróty}

$\begin{array}{llll}\text {-Ø } & \text { końcówka zerowa } & \text { GEN } & \text { genetivus } \\ \text { I, II, III } & \text { pierwszy, drugi, trzeci } & \text { INESS } & \text { inessivus } \\ {[]} & \text { znaczenie diatetyczne } & \text { INSTR } & \text { instrumentalis } \\ / & \text { granica między morfami } & \text { NOM } & \text { nominativus } \\ \text { ABL } & \text { ablativus } & \text { PL } & \text { pluralis } \\ \text { ACC } & \text { accusativus } & \text { PRAES } & \text { praesens } \\ \text { CAUS } & \text { causativum } & \text { PRAET } & \text { praeteritum } \\ \text { DAT } & \text { dativus } & \text { PROLAT } & \text { prolativus } \\ \text { EGRESS } & \text { egressivus } & \text { SG } & \text { singularis } \\ \text { ELAT } & \text { elativus } & \text { SUBST } & \text { substantivum }\end{array}$

\section{Bibliografia}

Bańczerowski J. Systems of Semantics and Syntax. A Determinational Theory of Language. WarszawaPoznań: Państwowe Wydawnictwo Naukowe, 1980.

Bartens R. Permiläisten kielten rakenne ja kehitys. Helsinki: Suomalais-Ugrilainen Seura, 2000. 
Bogusławski A., Drzazgowska E. Język w refleksji teoretycznej. Przekroje historyczne. Warszawa: Katedra Lingwistyki Formalnej Uniwersytetu Warszawskiego, 2016.

Castrén M.A. Elementa Grammatices Syrjaenae. Helsinki: Officina typographica heredum Simelii, 1844.

Csúcs S. A votják tárgyról. „Nyelvtudományi Közlemények” 2003, nr 100, s. 126-136.

Frege G. Pisma semantyczne. Warszawa: Państwowe Wydawnictwo Naukowe, 1977.

Hjelmslev L. La catégorie des cas. „Acta Jutlandica” 1937, nr IX 2, s. 1-184.

Jakobson R. Selected Writings II. World and Language. The Hague-Paris: Mouton, 1971.

Jespersen O. The Philosophy of Grammar. New York: The Norton Library, 1965.

Kuryłowicz J. Studia językoznawcze. Wybór prac opublikowanych w języku polskim. Warszawa: Państwowe Wydawnictwo Naukowe, 1987.

Rédei K. Die Postpositionen im Syrjänischen unter Berücksichtigung des Wotjakischen. Budapeszt: Akadémiai Kiadó, 1962.

Stipa G. Funktionen der Nominalformen des Verbs in den permischen Sprachen. Helsinki: SuomalaisUgrilainen Seura, 1960.

Wiedemann F. Grammatik der wotjakischen Sprache nebst einem kleinen wotjakisch-deutschen und deutsch-wotjakischen Wörterbuche. Tallin: Kluge \& Ströhm, 1851.

Zabrocki L. U podstaw struktury i rozwoju języka. Warszawa-Poznań: Państwowe Wydawnictwo Naukowe, 1980.

Владыкин В.Е., Христолюбова Л.С. Удмуртъёс. Ижевск: Удмуртия, 2008.

Грамматика современного удмуртского языка. Фонетика и морфология. Ред. П.Н. Перевощиков. Ижевск: Удмуртское Книжное Издательство, 1962.

Ефремов Д. Удмурт кылысь каронкыллэн управлениез сярысь. „Вестник Удмуртского университета. История и филология" 2009, nr 1, s. 43-54.

Карпова Л. Особенности функиионирования падежей в северных диалектах удмуртского языка. „Вестник Красноярского государственного педагогического университета им. В.П. Астафьева" 2011, nr 3, s. 231-236.

Кондратьева Н. Категория падежа имени существительного в удмуртском языке. Ижевск: Удмуртский университет, 2011.

Серебренников Б. Историческая морфология пермских языков. Москва: Издательство Академии Наук СССР, 1964. 